\title{
Nephron-Sparing Surgery versus Radical Nephrectomy in the Treatment of Intracapsular Renal Cell Carcinoma up to $7 \mathrm{~cm}$
}

\author{
Alessandro Antonelli *, Alberto Cozzoli, Maria Nicolai, Danilo Zani, Tiziano Zanotelli, \\ Laura Perucchini, Sergio Cosciani Cunico, Claudio Simeone \\ Department of Urology, University of Brescia, Brescia, Italy
}

\section{Article info}

Article history:

Accepted November 5, 2007

Published online ahead of

print on November 20, 2007

Keywords:

Nephrectomy

Nephron-sparing surgery

Renal cell carcinoma

Tumour diameter

\begin{abstract}
Objective: To compare the oncologic outcomes of nephron-sparing surgery versus radical nephrectomy in intracapsular renal cell carcinoma (RCC) up to $7 \mathrm{~cm}$ by reviewing surgical experience retrospectively.

Methods: Data from 1290 consecutive patients who had surgery for RCC have been stored in a dedicated database since 1983. We selected and reviewed those related to disease-free patients who had been treated for unilateral pT1a/pT1b pNo/Nx M0 carcinomas up to $7 \mathrm{~cm}$ and later followed for a minimum of $12 \mathrm{mo}$.

Results: A total of 642 patients with mean follow-up of 72.9 mo were selected; 313 had been treated for tumours $<4 \mathrm{~cm}$ in diameter (176 nephron-sparing surgery, 137 nephrectomy), whereas 329 had been treated for tumours measuring $\geq 4 \mathrm{~cm}$ (52 nephron-sparing surgery, 277 nephrectomy). The comparison between tumours $<4 \mathrm{~cm}$ or $\geq 4 \mathrm{~cm}$ in diameter showed worse progression and disease-free survival rates for the latter, but the type of surgery (nephron-sparing or radical) seemed to have no significant impact.

Conclusions: Conservative management can be cautiously suggested for RCC up to $7 \mathrm{~cm}$ because the worsening of prognosis as diameter increases shows no statistical differences for either nephron-sparing or radical surgery. The agreement of our results with those of similar studies available in the literature may suggest designing a prospective study to compare conservative and more radical surgery in the management of RCC up to $7 \mathrm{~cm}$.

(C) 2007 European Association of Urology. Published by Elsevier B.V. All rights reserved.

\footnotetext{
* Corresponding author. Department of Urology, Piazzale Spedali Civili no. 1, 25123 Brescia, Italy. Tel. +390303995215; Fax: +39030399002.

E-mail address: alxanto@hotmail.com (A. Antonelli).
} 


\section{Introduction}

Renal cell carcinoma (RCC) accounts for $2 \%$ of solid tumours and is the urologic malignancy associated with the highest mortality rate due to the lack of efficient systemic therapy in the treatment of metastatic diseases [1].

Radical surgery is still regarded as the gold standard in the management of organ-confined tumours and historically radical nephrectomy has been considered as the elective surgical option in case of a healthy contralateral kidney. However, a considerable number of clinical studies have already shown that nephron-sparing surgery ensures comparable oncologic outcomes for carcinomas $<4 \mathrm{~cm}$ in diameter, in addition to preserving renal function [2-9]. Furthermore, a number of recent case reviews based on large data sets coming from tertiary centres suggest extending elective indications to tumours up to $7 \mathrm{~cm}$ in diameter [10-16]. Although these recommendations are supported by numerous members of the urologic community, as the last European Association Guidelines have confirmed [17], in the clinical practice a considerable number of patients with small-sized tumours are still treated with radical nephrectomy, possibly on the grounds that this type of treatment is synonymous with better tumour control [18].

The purpose of this study, which is based on the review of a large number of cases of RCC up to $7 \mathrm{~cm}$ with no peri-renal invasion, no vascular or lymph node involvement, and no distant metastases, all treated at the same centre, is to contribute to proving the oncologic equivalence of radical and nephron-sparing surgery.

\section{Methods}

\subsection{Background}

The clinical, surgical, and anatomopathologic records of 1290 consecutive patients treated for RCC at our institution have been stored prospectively in a dedicated database since 1983. All cases were staged preoperatively with computed tomography (CT) or nuclear magnetic resonance (NMR). Overall, patients with a normal contralateral kidney were treated with nephron-sparing surgery in case of organ-confined tumours $<4 \mathrm{~cm}$ in diameter (elective indications), whereas tumours measuring $>4 \mathrm{~cm}$ and more advanced in staging were generally treated with radical nephrectomy. Nephron-sparing surgery was indicated for patients with an anatomically or functionally single kidney or suffering from chronic renal insufficiency, only given complete resectability of the tumour, regardless of its spread (imperative indications). Over the same period, only two uropathologists examined the surgical specimens. The tumour histologic type was redetermined according to the Heildelberg classification [19], grading was assigned according to Fuhrman [20], and staging was updated to the TNM 2002 system. All patients were periodically followed after surgery with clinical evaluations and instrumental examinations (chest radiography or CT, abdominal ultrasonography or CT) every 6 mo for the first $2 \mathrm{yr}$ and then once a year.

\subsection{Patient selection}

For this study we reviewed the records of patients treated with radical surgery (absence of residual disease) for tumours up to $7 \mathrm{~cm}$ in diameter with no evidence of fatty tissues invasion, vascular or lymph node involvement, or distant metastases (pT1a/pT1b pN0/Nx M0). Patients with synchronous bilateral tumours or urothelial tumour of the contralateral kidney were excluded from the study to prevent the oncologic outcome from being affected by the features of the second tumour. Disease-free patients with $<12$-mo follow-up were also excluded. Recurrence time and sites were inferred from postoperative controls and subclassified as recurrences in the kidney treated with nephron-sparing surgery, carcinomas developed in the contralateral kidney, local recurrences (lumbar fossa or retroperitoneal lymph nodes), and distant metastases.

\subsection{Statistical analysis}

Differences between continuous variables were estimated with the test, whereas differences between nominal variables were estimated with the $\chi^{2}$ test; survival analysis was performed according to the Kaplan-Meier method and differences were estimated with the log-rank test. Two-tail $p$ values were used for all tests and regarded as statistically relevant if $<0.05$ (SAS Institute software, version 5.0.1).

\section{Results}

\subsection{Patient and tumour characteristics}

Based on inclusion criteria, we selected 642 patients with mean age of $61.1 \mathrm{yr}$ (range: $21-88 \mathrm{yr}$ ) and maleto-female ratio of 1.6:1 from the complete data set. Mean follow-up was 72.9 mo (range: 6-295 mo) and $74.9 \mathrm{mo}$ (range: $12-295 \mathrm{mo}$ ) for presently disease-free cases; 15 patients with synchronous bilateral RCC, 3 patients with contralateral urothelial carcinoma, and 129 disease-free patients with $<12$-mo followup were excluded from the study.

Table 1 lists the features of patients grouped according to pathologic tumour diameter, that is, $<4$ or $\geq 4 \mathrm{~cm}$, and the type of selected surgery, nephron-sparing or radical. The comparison has shown a more unfavourable, though not always statistically relevant, distribution of the clinical and anatomopathologic characteristics under evaluation for the patients treated with radical 
Table 1 - Comparison of the characteristics of patients treated with either nephron-sparing surgery or radical nephrectomy

\begin{tabular}{|c|c|c|c|}
\hline & Nephron-sparing & Nephrectomy & $p$ \\
\hline Diameter $<4 \mathrm{~cm}$ & 176 patients & 137 patients & \\
\hline Incidental diagnosis & 136 pts $(77.8 \%)$ & 90 pts $(65.7 \%)$ & 0.0184 \\
\hline Clinical mean diameter (range) & $2.7 \mathrm{~cm}(1.0-5.0)$ & $3.6 \mathrm{~cm}(2.0-6.5)$ & $<0.0001$ \\
\hline Pathologic mean diameter (range) & $2.5 \mathrm{~cm}(0.5-3.8)$ & $2.9 \mathrm{~cm}(0.5-3.9)$ & $<0.0001$ \\
\hline Clinical T3a & 5 pts $(2.8 \%)$ & 10 pts $(7.3 \%)$ & 0.0670 \\
\hline Conventional histologic type & 143 pts $(81.2 \%)$ & 122 pts $(89.0 \%)$ & 0.0574 \\
\hline G3-4 & 28 pts $(17.2 \%)$ & 17 pts $(12.9 \%)$ & 0.3072 \\
\hline Mean follow-up & $59.2 \mathrm{mo}$ & $78.8 \mathrm{mo}$ & $<0.0001$ \\
\hline Imperative indication & 19 pts $(10.8 \%)$ & - & \\
\hline Diameter $\geq 4 \mathrm{~cm}$ & 52 patients & 277 patients & \\
\hline Incidental diagnosis & 37 pts $(71.1 \%)$ & 111 pts $(59.9 \%)$ & 0.0935 \\
\hline Clinical mean diameter (range) & $4.3 \mathrm{~cm}(2.0-12.0)$ & $5.5 \mathrm{~cm}(1.5-8.0)$ & $<0.0001$ \\
\hline Pathologic mean diameter (range) & $4.8 \mathrm{~cm}(4.0-7.0)$ & $5.2 \mathrm{~cm}(4.0-7.0)$ & 0.0136 \\
\hline Clinical T3a & 6 pts $(11.5 \%)$ & 57 pts $(20.6 \%)$ & 0.1285 \\
\hline Conventional histologic type & 42 pts $(80.8 \%)$ & 249 pts $(89.9 \%)$ & 0.0590 \\
\hline G3-4 & 13 pts $(25.0 \%)$ & 76 pts $(27.5 \%)$ & 0.7059 \\
\hline Mean follow-up & $54.3 \mathrm{mo}$ & $78.8 \mathrm{mo}$ & 0.0002 \\
\hline Imperative indication & 19 pts $(36.5 \%)$ & - & \\
\hline
\end{tabular}

nephrectomy and only conventional histologic type and high-grading rates have shown an overlapping distribution. Finally, the group of patients suffering from carcinomas $<4 \mathrm{~cm}$ included a fewer number of cases with imperative indication for conservative surgery $(10.9 \%$ vs. $36.5 \%, p<0.0001)$.

\subsection{Survival and variables affecting outcome}

To date, disease has recurred in 68 patients, equal to $10.6 \%$ of the sample, at a mean 42.7 mo after surgery (range: 3-291 mo). The cases with tumours $<4 \mathrm{~cm}$ or $\geq 4 \mathrm{~cm}$ have shown, respectively, progression rates of $8.6 \%$ and $12.5 \%(p=0.1144)$ and disease-free survival rates at $60 \mathrm{mo}$ of $96.9 \%$ and $92.4 \%$ $(p=0.0207)$.

After classifying tumours according to diameter, $<4 \mathrm{~cm}$ or $\geq 4 \mathrm{~cm}$, no statistically significant differences emerged in progression and survival rates depending on the type of surgery (Table 2). More specifically, the progression rate after radical sur- gery was twice that after nephron-sparing surgery for patients with tumours $\geq 4 \mathrm{~cm}(15.4 \%$ vs. $7.7 \%)$, even though no statistical significance can be attributed to these data.

Both after sparing and radical surgery, patients with carcinomas $<4 \mathrm{~cm}$ showed a higher risk of recurrence in the operated and contralateral kidney (obviously this figure is valid only for patients treated with conservative surgery), whereas patients with carcinomas $\geq 4 \mathrm{~cm}$ showed a higher risk of distant metastases and local recurrences (Table 3).

Cytonuclear grading was significantly correlated with the risk of recurrence in patients with carcinomas measuring $\geq 4 \mathrm{~cm}$ (low G vs, high G, $9.2 \%$ vs. $20.2 \%, p=0.0067)$, unlike patients with carcinomas $<4 \mathrm{~cm}$ (low G vs. high G, $7.6 \%$ vs. $11.1 \%, p=0.4277$ ). The type of surgery, however, had no significant impact on prognosis for patients with tumours $\geq 4 \mathrm{~cm}$ and high grading (Table 4).

Of 228 patients who had nephron-sparing surgery, 190 had elective and 38 had imperative

Table 2 - Progression rate and disease-free survival rate in patients treated with either nephron-sparing surgery or radical nephrectomy

\begin{tabular}{|c|c|c|c|c|c|}
\hline & & Progression rate & $p$ & Disease-free survival rate at $5 \mathrm{yr}$ & $p$ \\
\hline \multirow[t]{2}{*}{ Diameter $<4 \mathrm{~cm}$} & Nephron-sparing & $14 / 176$ pts $(8.0 \%)$ & 0.6314 & $96.1 \%$ & 0.7455 \\
\hline & Nephrectomy & $13 / 137$ pts $(9.5 \%)$ & & $97.5 \%$ & \\
\hline \multirow[t]{2}{*}{ Diameter $\geq 4 \mathrm{~cm}$} & Nephron-sparing & $4 / 52$ pts $(7.7 \%)$ & 0.2564 & $93.0 \%$ & 0.7463 \\
\hline & Nephrectomy & $37 / 277(15.4 \%)$ & & $92.5 \%$ & \\
\hline
\end{tabular}


Table 3 - Recurrence-specific risks associated to type of surgery and tumour diameter

\begin{tabular}{|c|c|c|c|c|c|}
\hline & & Distant metastases & Local recurrences & Contralateral kidney & Operated kidney \\
\hline \multirow[t]{2}{*}{ Nephron-sparing } & $<4 \mathrm{~cm}$ & 1 pt $(1.1 \%)$ & 1 pt $(0.6 \%)$ & 3 pts $(1.7 \%)$ & 8 pts $(4.4 \%)$ \\
\hline & $\geq 4 \mathrm{~cm}$ & 2 pts $(5.3 \%)$ & 1 pt $(1.9 \%)$ & $0.0 \%$ & 1 pt $(1.9 \%)$ \\
\hline \multirow[t]{2}{*}{ Nephrectomy } & $<4 \mathrm{~cm}$ & 5 pts $(3.7 \%)$ & $0.0 \%$ & 8 pts $(5.8 \%)$ & - \\
\hline & $\geq 4 \mathrm{~cm}$ & 32 pts $(11.6 \%)$ & $2 \mathrm{pt}(0.7 \%)$ & 3 pts $(1.1 \%)$ & - \\
\hline
\end{tabular}

Table 4 - Progression rate and disease-free survival rate in carcinomas $\geq 4 \mathrm{~cm}$ with high cytonuclear grading

\begin{tabular}{lcccc} 
& Progression rate & $p$ & Disease-free survival rate at 5 yr & $p$ \\
\hline Nephron-sparing & $15.3 \%(2 / 13 \mathrm{pts})$ & 0.6382 & $80.8 \%$ & 0.4790 \\
Nephrectomy & $21.0 \%(16 / 76 \mathrm{pts})$ & & $83.2 \%$ & \\
\hline Pts = patients. & & & \\
\hline
\end{tabular}

indications (chronic renal failure in 11 patients, contralateral renal atrophy in 11 patients, previous nephrectomy for benign disease in 10 patients, and congenital single kidney in 6 patients). Patients with elective indications showed a lower recurrence rate (5.7\% vs. $18.4 \%, p=0.0084$ ) and a higher disease-free survival rate at 5 yr $(96.3 \%$ vs. $90.5 \%, p=0.1089)$ than the patients with imperative indications. Considering also the size parameter, for tumours $<4 \mathrm{~cm}$ in diameter prognosis proved more favourable for the group treated with conservative surgery under elective indications, whereas the correlation was considerably less apparent for tumours $>4 \mathrm{~cm}$ in diameter (Table 5).

\section{Discussion}

Since the publication of Robson's study in 1969 [21], radical nephrectomy has been regarded as the gold standard to treat RCC. However, a good oncologic outcome from nephron-sparing surgery under imperative conditions and the ever-increasing occurrence of incidental small-sized tumours have encouraged surgeons to opt for organ-saving techniques also under elective conditions, giving survival rates that practically overlap those of radical nephrectomy $[2-9,22]$. Sparing surgery specifically entails the risk of recurrence in the operated organ, ranging between $0 \%$ and $10 \%$ in the major series [5], which can be imputed in principle to lack of radicality or undetected multifocality. So, the relationship between tumour size and multifocality identified by some anatomopathologic studies $[23,24]$ and the significantly worse oncologic outcome associated with the increase of diameter highlighted by some retrospective clinical studies [25] have led to the definition of a 4-cm cut-off point for elective nephron-sparing surgery, recommended by international guidelines and included in the TNM 2002 system to discriminate the pT1a from the pT1b stage. However, some studies have reconsidered the relationship between multifocality and diameter [26-30], pointing out that prognosis tends to worsen as diameter increases not only for patients treated with nephron-sparing surgery but also for patients treated with radical nephrectomy [31], expressing some criticism against the use of tumour diameter as the main parameter for planning surgical strategy.

Following these considerations, a limited number of retrospective studies from tertiary centres for the treatment of RCC have recently reported

Table 5 - Progression rate and disease-free survival rate in carcinomas $\geq 4 \mathrm{~cm}$ according to elective or imperative indications for conservative surgery

\begin{tabular}{|c|c|c|c|c|c|}
\hline & & Progression rate & $p$ & Disease-free survival rate at $5 \mathrm{yr}$ & $p$ \\
\hline \multirow{2}{*}{ Diameter $<4 \mathrm{~cm}$} & Elective & 9/157 pts $(5.7 \%)$ & 0.0017 & $97.3 \%$ & 0.0454 \\
\hline & Imperative & $5 / 19$ pts $(26.3 \%)$ & & $85.6 \%$ & \\
\hline \multirow[t]{2}{*}{ Diameter $\geq 4 \mathrm{~cm}$} & Elective & $2 / 33$ pts $(6.1 \%)$ & 0.5606 & $91.1 \%$ & 0.8271 \\
\hline & Imperative & $2 / 19(10.5 \%)$ & & $94.7 \%$ & \\
\hline
\end{tabular}


satisfactory oncologic outcomes [10-16] and acceptable morbidity [32] with the use of sparing surgery for tumours between 4 and $7 \mathrm{~cm}$, cautiously suggesting to extend elective indications to this diameter. Accordingly, the latest European guidelines recommend conservative surgery for tumours $<4 \mathrm{~cm}$ in diameter as the gold standard, although they admit, without recommending it, for tumours up to $7 \mathrm{~cm}$, provided cases are adequately selected and treated in experienced centres [17].

However, as the data reported by Miller et al [18] show, conservative surgery finds little application in clinical practice, even for small-sized tumours, possibly because most urologists still believe that radical surgery ensures better oncologic control.

For our study, we selected 642 cases of unilateral RCC measuring up to $7 \mathrm{~cm}$ with no extracapsular extension, no vascular invasion, and no lymph node or distant metastases, that had been followed up for a considerably long time.

Our results show that prognostic indicators are more favourable for patients with tumours $<4 \mathrm{~cm}$. Data stratification based on this diameter shows no differences in progression and survival rates between the cases treated with sparing or radical surgery; the figures are slightly in favour of the former, both for tumours $<4 \mathrm{~cm}$ and for larger tumours. Therefore, the selected type of surgery does not seem to have an impact on prognosis for these groups of patients.

Moreover, the way in which disease recurred appears to be related to the characteristics of the tumour regardless of the selected type of surgery because a greater risk of distant metastases and local recurrences was reported for carcinomas $\geq 4 \mathrm{~cm}$, whereas a greater risk of homolateral or contralateral renal recurrences was associated with carcinomas $<4 \mathrm{~cm}$, both for patients subjected to nephron-sparing surgery and nephrectomy. Relapse modalities had a different clinical behaviour. It was unfavourable for distant metastasis and local recurrences (22\% of presently disease-free cases), probably due to distant or regional micrometastases already present at diagnosis that were not affected by the treatment applied on the renal tumour. On the contrary, it was more indolent and responsive to surgical therapy for renal recurrences $(73 \%$ of disease-free cases), which can probably be regarded as newborn cancers instead of true tumour recurrences. This would further support the choice of conservative surgery to manage the first tumour and reduce the risk of renal failure when treating the second tumour.

Even if a significant correlation has been identified between high grade and poor prognosis for carcinomas $\geq 4 \mathrm{~cm}$, no impact of the type of surgery performed has been seen. Therefore, tumour grading assessment by preoperative or intraoperative biopsy is not essential because surgical strategy should not be influenced by this factor.

In our experience, patients treated with conservative surgery under imperative indications showed a tendency towards more unfavourable prognostic indicators than those treated under elective indications, but this correlation is far less apparent for carcinomas $\geq 4 \mathrm{~cm}$ in diameter. Considering that the small number of patients with imperative indications included in the series selected for this study makes statistical assessments less easy to interpret, we believe that the exclusion of patients with oncologic diseases affecting the contralateral kidney justifies the partial deviation from the data of other authors, who found in imperative indications a negative independent prognostic factor. Moreover, if we consider that the preservation of renal function is an even more stringent goal under those conditions since the oncologic benefit of radical nephrectomy has not been proved yet, the intuitive conclusion is that surgery should be conservative.

When discussing results, it must be noted, as Campbell and Novick have already pointed out [33], that the comparison between radical nephrectomy and nephron-sparing surgery in retrospective studies is based on groups of patients with hardly overlapping features, which makes the alleged equivalence of the two techniques rather questionable. Even in our study the heterogeneous distribution of clinical and pathologic parameters between groups suggests significant biases arise not only from the retrospective nature of the study but also, and in particular, from the criteria adopted to select patients for sparing surgery, which usually follow accepted guidelines that, until recently, were clearly against the elective use of that technique for tumours measuring $>4 \mathrm{~cm}$. Accordingly, only a few patients with such tumours underwent elective conservative treatment because of tumour diameter under-staging or "poorly aggressive" appearance at preoperative and intraoperative evaluations. At the same time, it should be noted that the seven papers [10-16] published to date on the same subject share identical selection biases and, despite a few differences in case selection, report virtually overlapping oncologic outcomes (Table 6).

The agreement between the results of papers published by different institutions may pave the way for the design of a prospective study to confirm the validity of nephron-sparing surgery as against radical nephrectomy for a selected number of renal tumours from 4 up to $7 \mathrm{~cm}$ in diameter. 
Table 6 - Results reported by the studies on conservative management of renal cell carcinomas between 4 and $7 \mathrm{~cm}$ in diameter available in literature

\begin{tabular}{lcclc}
\hline Study & $\begin{array}{c}\text { No. of } \\
\text { cases } \geq \mathbf{~ c m}\end{array}$ & Follow-up, mo & \% pT3a & $\begin{array}{c}\text { Disease-free survival } \\
\text { rate at 5 yr }\end{array}$ \\
\hline Carini et al [10] & 71 & 74 & $14 \%$ & $85.1 \%$ \\
Leibovich et al [11] & 91 & 106 & $1 \%$ & $98.0 \%$ \\
Patard et al [12] & 28 & 42 & $0 \%$ & $93.8 \%$ \\
Becker et al [13] & 69 & 74 & $4.3 \%$ & $94.9 \%$ \\
Dash et al [14] & 45 & 14 & $9 \%(2 \%$ with vascular invasion) & around $80 \%$ (figure not reported) \\
Mitchell et al [15] & 33 & 34 & $36.4 \%$ & $96.2 \%$ \\
Nemr at al [16] & 15 & 45 & Not reported & $100.0 \%$ \\
Present study & 52 & 54 & $0 \%$ & $93.0 \%$ \\
\hline
\end{tabular}

\section{Conclusion}

The retrospective review of our experience confirms the feasibility of nephron-sparing surgery for RCC between 4 and $7 \mathrm{~cm}$, provided tumours are carefully selected based on their safe and complete resectability. Considering the substantial agreement of our results with those reported by the few similar studies available in the literature, we believe the design of prospective studies that can confirm the equivalence of radical and conservative surgery in the management of organ-confined RCC up to $7 \mathrm{~cm}$ may be justified.

\section{Conflicts of interest}

The authors have nothing to disclose.

\section{References}

[1] Jemal A, Tiwari RC, Murray T, et al. Cancer statistics 2004. CA Cancer J Clin 2004;54:8-29.

[2] Morgan WR, Zincke H. Progression and survival after renalconserving surgery for renal cell carcinoma: experience in 104 patients and extended follow-up. J Urol 1990;144:852-7.

[3] Uzzo RG, Novick AC. Nephron sparing surgery for renal tumors: indications, techniques and outcomes. J Urol 2001;166:6-18.

[4] Pahernik S, Roos F, Hampel C, Gillitzer R, Melchior SW, Thuroff JW. Nephron sparing surgery for renal cell carcinoma with normal contralateral kidney: 25 years of experience. J Urol 2006;175:2027-31.

[5] Hafez KS, Novick AC, Campbell SC. Patterns of tumor recurrence and guidelines for follow up after nephron sparing surgery for sporadic renal cell carcinoma. J Urol 1997;157:2067-70.

[6] Lau WK, Blute ML, Weaver AL, Torres VE, Zincke H. Matched comparison of radical nephrectomy vs nephron sparing surgery in patients with unilateral renal cell carcinoma and a normal contralateral kidney. Mayo Clin Proc 2000;75:1236-42.
[7] Lee CT, Katz J, Shi W, Thaler HT, Reuter VE, Russo P. Surgical management of renal tumors $4 \mathrm{~cm}$. or less in a contemporary cohort. J Urol 2000;163:730-6.

[8] Lerner SE, Hawkins CA, Blute ML, et al. Disease outcome in patients with low stage renal cell carcinoma treated with nephron sparing or radical surgery. J Urol 1996;155:1868-73.

[9] Van Poppel H, Bamelis B, Oyen R, Baert L. Partial nephrectomy for renal cell carcinoma can achieve long-term tumor control. J Urol 1998;160:674-8.

[10] Carini M, Minervini A, Lapini A, Serni S, Masieri L. Simple enucleation for the treatment of renal cell carcinoma between 4 and $7 \mathrm{~cm}$ in greatest dimension: progression and long-term survival. J Urol 2006;175:2022-6.

[11] Leibovich BC, Blute NK, Cheville JC, Lohse CM, Weaver AL, Zincke H. Nephron sparing surgery for appropriately selected renal cell carcinoma between 4 and $7 \mathrm{~cm}$ results in outcome similar to radical nephrectomy. J Urol 2004;171:1066-70.

[12] Patard J-J, Shvarts O, Lam JS, et al. Safety and efficacy of partial nephrectomy for all T1 tumors based on an international multicenter experience. J Urol 2004;171:2181-5.

[13] Becker F, Siemer S, Hack M, Humke U, Ziegler M, Stöckle M. Excellent long-term cancer control with elective nephron-sparing surgery for selected renal cell carcinomas measuring more than $4 \mathrm{~cm}$. Eur Urol 2006;49:1058-64.

[14] Dash A, Vickers AJ, Schachter LR, Bach AM, Snyder ME, Russo P. Comparison of outcomes in elective partial vs radical nephrectomy for clear cell renal cell carcinoma of 4-7 cm. BJU Int 2006;97:939-45.

[15] Mitchell RE, Gilbert SM, Murphy AM, Olsson CA, Benson MC, McKiernan JM. Partial nephrectomy and radical nephrectomy offer similar cancer outcomes in renal cortical tumors $4 \mathrm{~cm}$ or larger. Urology 2006;67:260-4.

[16] Nemr E, Azar G, Fakih F, et al. Partial nephrectomy for renal cancers larger than $4 \mathrm{~cm}$. Prog Urol 2007;17:810-4.

[17] Ljungberg B, Hanbury DC, Kuczyk MA, et al. Renal cell carcinoma guideline. Eur Urol 2007;51:1502-10.

[18] Miller DC, Hollingsworth JM, Hafez KS, Daignault S, Hollenbeck BK. Partial nephrectomy for small renal masses: an emerging quality of care concern? J Urol 2006;175:853-7, discussion 858.

[19] Kovacs G, Akhtar M, Beckwith BJ, et al. The Heidelberg classification of renal cell tumors [editorial]. J Pathol 1997;183:131-3. 
[20] Fuhrman SA, Lasky LC, Limas C. Prognostic significance of morphologic parameters in renal cell carcinoma. Am J Surg Pathol 1982;6:655-63.

[21] Robson CJ, Churchill BM, Anderson W. The results of radical nephrectomy for renal cell carcinoma. J Urol 1969;101:297-301.

[22] Fergany AF, Hafez KS, Novick AC. Long-term results of nephron sparing surgery for localized renal cell carcinoma: 10-year follow up. J Urol 2000;163:442-5.

[23] Mukamel E, Konichezky M, Engelstein D, Servadio C. Incidental small renal tumors accompanying clinically overt renal cell carcinoma. J Urol 1988;140:22-4.

[24] Miller J, Fischer C, Freese R, Altmannsberger M, Weidner W. Nephron sparing surgery for renal cell carcinoma: is tumor size a suitable parameter for indication? Urology 1999;54:988-93.

[25] Hafez KS, Fergany AF, Novick AC. Nephron sparing surgery for localized renal cell carcinoma: impact of tumor size on patient survival, tumor recurrence and TNM staging. J Urol 1999;162:1930-3.

[26] Kletscher BA, Qian J, Bostwick DG, Andrews PE, Zincke H. Prospective analysis of multifocality in renal cell carcinoma: influence of histological pattern, grade, number, size, volume and deoxyribonucleic acid ploidy. J Urol 1995;153:904-6.
[27] Li Q, Guan H, Zhang Q, Xue J, Wang F, Song X. Multicentricity and its associated factors in renal cell carcinoma in Chinese patients. Chin Med J 2002;115:1341-4.

[28] Baltaci S, Orhan D, Soyupek S, Bedük Y, Tulunay O, Gögüs O. Influence of tumor stage, size, grade, vascular involvement, histological cell type and histological pattern on multifocality of renal cell carcinoma. J Urol 2000;164:36-9.

[29] Gohji K, Hara I, Gotoh A, et al. Multifocal renal cell carcinoma in Japanese patients with tumors with maximal diameter of $50 \mathrm{~mm}$ or less. J Urol 1998;159:1144-7.

[30] DiMarco DS, Lohse CM, Zincke H, Cheville JC, Blute ML. Sporadic multifocal renal cell carcinoma according to histologic subtype compared with patients with solitary tumors after radical nephrectomy. Urology 2004;64: 462-7.

[31] Steiner T, Knels R, Schubert J. Prognostic significance of tumour size in patients after tumour nephrectomy for localised renal cell carcinoma. Eur Urol 2004;46:327-30.

[32] Patard J-J, Pantuck AJ, Crepel M, et al. Morbidity and clinical outcome of nephron-sparing surgery in relation to tumour size and indication. Eur Urol 2007;52:148-54.

[33] Campbell SC, Novick AC. Expanding the indications for elective partial nephrectomy: is this advisable? Eur Urol 2006;49:952-4. 